\title{
ZASADY DOBORU WSPÓŁCZYNNIKA CAŁKOWITEJ PRZEPUSZCZALNOŚCI ENERGII PROMIENIOWANIA SLONECZNEGO PRZESZKLEŃ W ENERGOOSZCZĘDNYCH BUDYNKACH JEDNORODZINNYCH
}

\begin{abstract}
Przeszklenia w budownictwie jednorodzinnym energooszczędnym pełnią istotną funkcję w kształtowaniu bilansu energetycznego budynku. Przez przeszklenia zachodzi strata ciepła przez przenikanie. Dzięki przeszkleniom zachodzi również uzysk energii cieplnej z promieniowania słonecznego. Nadmierny uzysk energii cieplnej w okresie letnim może doprowadzać do przegrzewania się pomieszczeń i jest zjawiskiem niepożądanym. Ściany budynków energooszczędnych charakteryzują się dodatkowo dość niskim współczynnikiem przenikania ciepła, co utrudnia odprowadzanie nadmiaru zysków słonecznych z pomieszczeń. Ekspozycja warstw akumulacyjnych na promieniowanie słoneczne w okresie letnim jest również zjawiskiem niekorzystnym. Warstwy akumulacyjne oddają uzyskane ciepło z parogodzinnym przesunięciem w czasie i ich niekorzystne usytuowanie może doprowadzić do przegrzewania się pomieszczeń. Niezbędny staje się system wentylacji pomieszczeń, który usuwa nadmiar ciepła. Nadmierne zyski słoneczne powodują konieczność intensywniejszej pracy instalacji wentylacji sprzyjając zwiększeniu energochłonności budynku. $\mathrm{Z}$ tego powodu odpowiednie umieszczenie przeszkleń w bryle budynku, ich wielkość, orientacja względem stron świata oraz parametry stosowanego szkła są niezwykle istotne w kształtowaniu struktury budynku energooszczędnego. Współczynnik całkowitej przepuszczalności energii promieniowania słonecznego „g” określa, w jakim stopniu energia promieniowania słonecznego przenika przez szybę do wnętrza. Większa wartość współczynnika oznacza, że zyski energetyczne są wyższe. Zyski z promieniowania słonecznego w okresie zimowym są korzystne i przyczyniają się do poprawy bilansu energetycznego budynku. Ukształtowanie struktury budynku jednorodzinnego energooszczędnego powinno umożliwiać zatem zyski z promieniowania słonecznego w okresie zimowym oraz w okresach przejściowych, a zapobiegać ich powstawaniu w okresie letnim.
\end{abstract}

Słowa kluczowe: jednorodzinne budownictwo energooszczędne, współczynnik całkowitej przepuszczalności energii promieniowania słonecznego, zyski solarne

\footnotetext{
${ }^{1}$ Iwona Piebiak, Politechnika Krakowska, Instytut Projektowania Budowlanego, ul. Podchorążych 1, 30-084 Kraków, tel. 12628-2459
} 


\section{Wstęp}

Wymogiem współczesnych trendów projektowych w architekturze, również w kształtowaniu domów jednorodzinnych, jest otwieranie przy pomocy dużych przeszkleń widoków z wnętrz budynków na otoczenie. Duże przeszklenia utożsamiane z wysokim standardem współczesnej architektury stanowią często symbol prestiżu dla Inwestora. Stosowanie przeszkleń w dużych rozmiarach niewątpliwie polepsza kontakt wzrokowy użytkownika budynku $\mathrm{z}$ otoczeniem oraz sprzyja lepszemu doświetleniu pomieszczeń, nie pozostaje jednak bez wpływu na bilans energetyczny obiektu.

Przeszklenia stosowane obecnie w budownictwie charakteryzują się wyższym współczynnikiem przenikania ciepła niż przegrody pełne: dachy, stropodachy, ściany ${ }^{2}$. Stosowanie dużych przeszkleń w przegrodach równoznaczne jest zatem z większymi stratami ciepła. Straty ciepła przez przenikanie przez przegrody przeszklone mogą zostać zrekompensowane zyskami ciepła przez przeszklenia skierowane w kierunku południowym. Przepisy rozporządzenia Ministerstwa Transportu, Budownictwa i Gospodarki Morskiej „W sprawie warunków technicznych, jakim powinny odpowiadać budynki i ich usytuowanie", które obowiązują od 1 stycznia 2014 r., wprowadziły zaostrzenie wymogów termoizolacyjności parametrów okien i drzwi balkonowych. Wprowadziły również konieczność obniżania współczynnika przepuszczalności energii całkowitej promieniowania słonecznego „g" dla okien oraz przegród przezroczystych. Współczynnik „g” nie może być większy niż 0,35 w okresie letnim. Warunku tego nie muszą spełniać przeszklenia skierowane na północny-wschód, północ, północny-zachód, odchylone o więcej niż 60 stopni od poziomu oraz chronione przed promieniowaniem słonecznym przy pomocy elementów zacieniających. Współczynnik ,g” dla danego przeszklenia oblicza się wg wzoru:

$$
g=f_{c} \times g_{n}
$$

gdzie $\mathrm{f}_{\mathrm{c}}$ oznacza współczynnik redukcji promieniowania ze względu na zastosowane urządzenia przeciwsłoneczne, a $\mathrm{g}_{\mathrm{n}}$ współczynnik całkowitej przepuszczalności energii promieniowania słonecznego dla danego typu przeszklenia ${ }^{3}$. Całkowity współczynnik przenikalności energii „g” [\%] dla danego przeszklenia

\footnotetext{
${ }^{2}$ Współczynnik przenikania ciepła U wg Rozporządzenia Ministra Infrastruktury w sprawie warunków technicznych jakim powinny odpowiadać budynki i ich usytuowanie, wymagania od 1 stycznia 2021 r.: Okna, drzwi balkonowe, powierzchnie przezroczyste nieotwieralne: $0,9 \mathrm{~W} / \mathrm{m}^{2} \mathrm{~K}$; dachy, stropodachy: $0,15 \mathrm{~W} / \mathrm{m}^{2} \mathrm{~K}$; ściany zewnętrzne: $0,2 \mathrm{~W} / \mathrm{m}^{2} \mathrm{~K}$

${ }^{3}$ Artykuł nie zawiera szczegółowego sposobu obliczania współczynnika „g” oraz nie omawia szczegółowo wartości współczynnika redukcji promieniowania słonecznego ze względu na zastosowane urządzenia przeciwsłoneczne. Metodę obliczeń oraz wartości współczynników zawiera rozporządzenia Ministerstwa Transportu, Budownictwa i Gospodarki Morskiej „W sprawie warunków technicznych, jakim powinny odpowiadać budynki i ich usytuowanie” z dnia 12 kwietnia 2002 r. późniejszymi zmianami
} 
określa jaka wartość promieniowania słonecznego padającego na szybę zostaje przepuszczona do wnętrza pomieszczenia. Największe zyski energetyczne osiąga się zatem przy pomocy okien, których szyby maja wysoki współczynnik przepuszczalności energii słonecznej.

\section{Teza badawcza}

Zmniejszenie maksymalnej wartości współczynnika całkowitej przepuszczalności energii słonecznej ma istotne znaczenie w przypadku budynków z wielkopowierzchniowymi przeszkleniami, w których do chłodzenia latem zużywa się znacznie więcej energii niż do ogrzewania zimą, np. obiektów biurowych, handlowych, komercyjnych. W przypadku energooszczędnych budynków mieszkalnych, w których wielkie przeszklenia projektuje się w ilości umiarkowanej, celem jest uzyskanie odpowiednio niskich kosztów ogrzewania zimą. Na poprawę bilansu energetycznego wpływają wówczas bierne zyski z promieniowania słonecznego uzyskiwane dzięki przeszkleniom. Zyski z promieniowania słonecznego pożądane w okresie zimowym, powinny być ograniczane w okresie letnim.

Ochronę przed przegrzaniem pomieszczeń w okresie letnim oraz redukcję współczynnika całkowitej przepuszczalności energii promieniowania słonecznego, można uzyskać przy pomocy powłok selektywnych, osłon przeciwsłonecznych zewnętrznych (daszki zacieniające, markizy), osłon przeciwsłonecznych wewnętrznych (rolety, żaluzje), czy osłon przeciwsłonecznych zintegrowanych z zestawami szklanymi, zamkniętych pomiędzy taflami szkła. Można też wyróżnić sezonowe (naturalne) osłony przeciwsłoneczne, w postaci roślinności zrzucającej liście w zimie. Miejsce umieszczenia osłon przeciwsłonecznych nie jest bez znaczenia ze względu na bilans energetyczny budynku. Istotną redukcję energii $\mathrm{z}$ promieniowania słonecznego zapewniają osłony przeciwsłoneczne umieszczone przed przegrodą, mniej efektywne są te umieszczone wewnątrz zestawów, a najmniej - wewnątrz pomieszczenia [1]. Powłoki selektywne zmniejszają wielkość współczynnika całkowitej przepuszczalności energii promieniowania słonecznego zarówno w okresie zimowym jak i letnim. Na rynku budowlanym pojawiły się już rozwiązania techniczne, umożliwiające zastosowanie szyb z powłoka selektywną, których współczynnik ,g” wynosi wymagane regulacjami prawnymi 0,35 . (tab. 1). Ich zastosowanie w budynkach jednorodzinnych energooszczędnych skutkuje ochroną wnętrz przed przegrzaniem w lecie, lecz również zmniejszeniem zysków słonecznych w okresie zimowym. Decyzja projektowa o zastosowaniu tego typu przeszklenia wydaje się być uzasadniona zastosowaniem w energooszczędnym budynku jednorodzinnym wielko powierzchniowych przeszkleń od strony południowej, wschodniej oraz zachodniej, które umożliwią osiągnięcie odpowiednich zysków solarnych w okresie zimowym.

W wytycznych do weryfikacji projektów budynków mieszkalnych, zgodnych ze standardem NFOŚiG [3, 4], zaznaczono, iż zastosowany rodzaj szyb 
w budownictwie energooszczędnym powinien charakteryzować się możliwie wysokim współczynnikiem przepuszczalności energii promieniowania słonecznego „g”, który w przypadku szyb podwójnych powinien wynosić przynajmniej 0,60, a dla szyb potrójnych 0,5 . Z analizy wytycznych NFOŚiG oraz z parametrów podawanych przez producentów przeszkleń, jak również obowiązujących regulacji prawnych wynika, iż zastosowanie w budynku energooszczędnym przeszkleń z powłoką selektywną o współczynniku g = 0,67 dla podwójnego szklenia i g= 0,5 dla potrójnego, nie chroni w okresie letnim w sposób wystarczający wnętrz przed przegrzaniem i wymaga zastosowania dodatkowych osłon przeciwsłonecznych. Zastosowanie przeszkleń o współczynniku g=0,35 lub g=0,27 uniemożliwia natomiast osiągnięcie wystarczających zysków solarnych zimą.

Tabela. 1. Współczynnik całkowitej przepuszczalności energii promieniowania słonecznego „g” dla różnych typów przeszkleń, na podstawie $[2,5]$

Table 1. Total solar energy transmittance factor ,g” for different types of glazing, based on $[2,5]$

\begin{tabular}{|c|c|}
\hline Rodzaj przeszklenia & $\begin{array}{c}\text { Współczynnik całkowitej przepuszczalności } \\
\text { energii promieniowania słonecznego ,g”, }\end{array}$ \\
\hline Przeszklenie pojedyncze & 0,85 \\
\hline Przeszklenie podwójne & 0,75 \\
\hline Przeszklenie podwójne z powłoka selektywną & 0,67 \\
\hline Przeszklenie potrójne & 0,7 \\
\hline Przeszklenie potrójne z powłoka selektywną & 0,5 \\
\hline Pilkington Suncool 66/33 & 0,35 \\
\hline Pilkington Suncool 50/25 & 0,27 \\
\hline
\end{tabular}

\section{Metoda ustalania współczynnika ,g” dla przeszkleń w energooszczędnym budynku jednorodzinnym wolnostojącym. Studium przypadku}

Analizowany obiekt jest budynkiem mieszkalnym, jednorodzinnym, dwukondygnacyjnym, niepodpiwniczonym, projektowanym w Katowicach (rys. 1). Powierzchnia użytkowa budynku wynosi $290,56 \mathrm{~m}^{2}$. Powierzchnia zabudowy $346,45 \mathrm{~m}^{2}$. Budynek zlokalizowano na działce o niekorzystnym ukierunkowaniu względem stron świata. Wjazd na teren działki znajduje się od strony południowej. Obowiązująca na danym obszarze linia zabudowy wymusiła lokalizację budynku w bliskim sąsiedztwie drogi dojazdowej, uniemożliwiając przesunięcie go w głąb działki. $Z$ tego powodu projektanci zdecydowali o konieczności zastosowania rozczłonkowanej formy budynku, $\mathrm{z}$ wewnętrznym dziedzińcem odgrodzonym od strony drogi dojazdowej częścią kubatury. Ze względu na zapotrzebowanie inwestora na niewielką powierzchnię użytkową, wielkość dziedzińca, a tym samym odsuniecie od przeciwległego skrzydła budynku, również było niewielkie i wynosiło ok. 8 metrów. Po analizach nasłonecznienia bryły budynku okazało się, że 8 metrowe oddalenie od skrzydła południowego budynku, nie jest wystarczające ze względu na zyski słoneczne w zimie. Wewnętrzna elewa- 


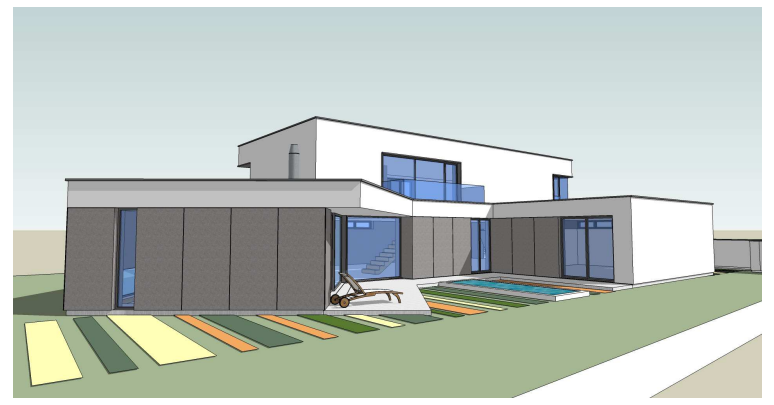

Rys. 1. Budynek jednorodzinny w Katowicach, arch. Jacek Dyga, Paweł Grzyb, Iwona Piebiak, MINT Architecture, 2015 r.; widok od strony zachodniej

Fig. 1. Single-family house in Katowice, arch. Jacek Dyga, Paweł Grzyb, Iwona Piebiak, MINT Architecture, 2015 r,; view from the west

cja południowa, z dużymi przeszkleniami, pozostawała zacieniona $\mathrm{w}$ okresie zimowym. To skłoniło projektantów do przekrzywienia bryły budynku i skierowania głównych przeszkleń doświetlających część dzienną budynku w kierunku południowo-zachodnim (rys. 2).

Analiza lokalizacji przeszkleń względem stron świata oraz nasłonecznienia bryły budynku skutkowała następującym doborem współczynnika przepuszczalności całkowitej promieniowania słonecznego „g” dla przeszkleń budynku:

1. Przeszklenia od strony południowej, od strony wewnętrznego dziecińca, zostały wyposażone $\mathrm{w}$ zewnętrzną osłonę przeciwsłoneczną w postaci zadaszenia nad przeszkleniami. Zadaszenie to zacienia przeszklenia w okresie letnim, umożliwia (poprzez dodatkowe przekrzywienie bryły budynku w kierunku południowo-zachodnim) dostęp bezpośredniego promieniowania słonecznego w zimie. Współczynnik ,g” dla tego przeszklenia wynosi 0,7, współczynnik U (ze względu na wielkość przeszkleń) $=0,9 \mathrm{~W} / \mathrm{m}^{2} \mathrm{~K}$.

2. Przeszklenia od południa, od strony drogi dojazdowej, zostały wyposażone w wewnętrzne białe żaluzje o lamelach nastawnych. Współczynnik „g” dla tych przeszkleń w lecie wynosi 0,34 , współczynnik $\mathrm{U}=1,1 \mathrm{~W} / \mathrm{m}^{2} \mathrm{~K}$.

3. Przeszklenia doświetlające sypialnie, zlokalizowane od strony wschodniej oraz zachodniej, również zostały wyposażone w wewnętrzne białe żaluzje o lamelach nastawnych. Współczynnik ,g” dla tych przeszkleń w lecie wynosi 0,34 , współczynnik $\mathrm{U}=1,1 \mathrm{~W} / \mathrm{m}^{2} \mathrm{~K}$.

4. Część przeszkleń w budynku została zlokalizowana w elewacjach północnych bądź północno-wschodnich. Okna w tych fasadach będą miały ujemny bilans energetyczny w okresie grzewczym (straty ciepła będą większe niż zyski energetyczne). W celu zmniejszenia strat ciepła, współczynnik U dla okien będzie wynosił $0,9 \mathrm{~W} / \mathrm{m}^{2} \mathrm{~K}$. Lokalizacja okien od strony północnej budynku została podyktowana otwarciami widokowymi z wnętrza budynku na ogród.

Zastosowane rozwiązania projektowe umożliwiły uzyskanie wskaźnika EP. 

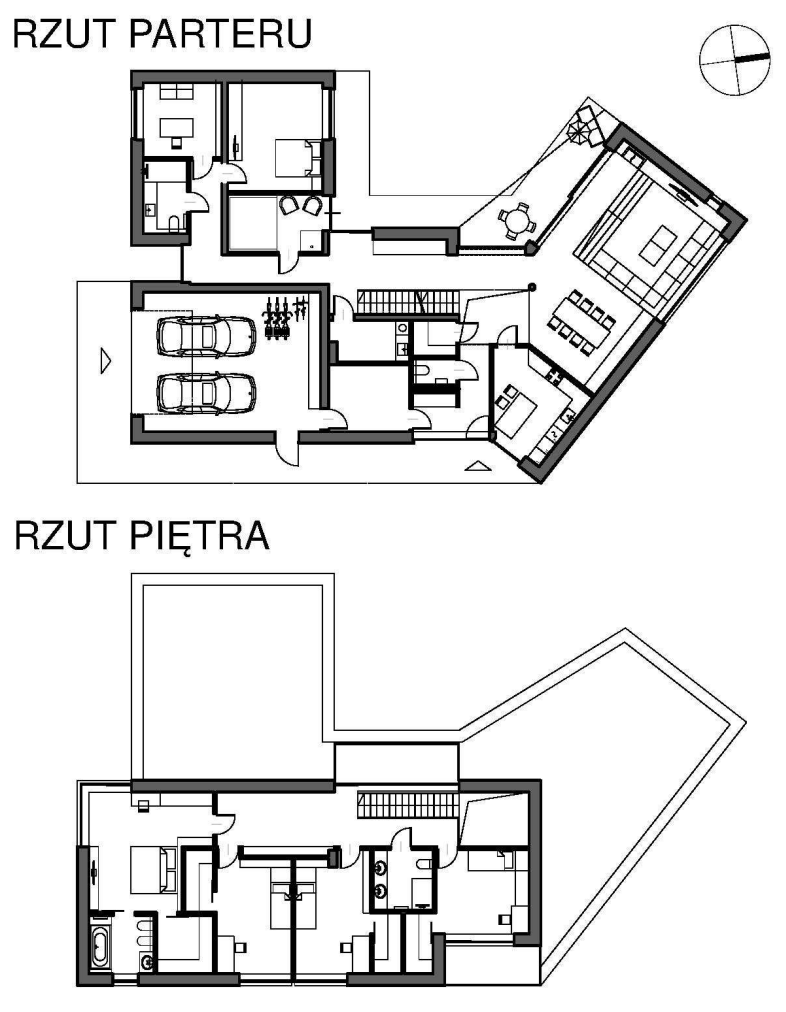

$0 .+, ., 10$

Rys. 2. Budynek jednorodzinny w Katowicach, arch. Jacek Dyga, Paweł Grzyb, Iwona Piebiak, MINT Architecture, 2015 r.

Fig. 2. Single-family house in Katowice, arch. Jacek Dyga, Paweł Grzyb, Iwona Piebiak, MINT Architecture, 2015 r.; ground floor; first floor

\section{Wnioski}

Przy doborze rodzaju szkła w przeszkleniach w budownictwie mieszkalnym jednorodzinnym, oprócz aspektu ograniczania strat energii przez przenikanie, istotną właściwością jest możliwy korzystny wpływ przeszkleń na poprawę bilansu energetyczny całego obiektu budowlanego, szczególnie w okresie sezonu grzewczego. Uzysk energii z promieniowania słonecznego jest zjawiskiem niepożądanym w okresie letnim, korzystnym w sezonie zimowym oraz okresach przejściowych. Dobór rozwiązań projektowych i materiałowych stosowanych w energooszczędnym budownictwie jednorodzinnym, powinien umożliwić uzysk energii z promieniowania słonecznego $\mathrm{w}$ okresach zapotrzebowania na ogrzewanie budynku oraz ochronę przed przegrzaniem wnętrz budynków 
w okresie letnim. Powłoka selektywna ogranicza uzysk energii z promieniowania słonecznego latem, lecz również zimą. Sezonowe osłony przeciwsłoneczne nie ograniczają dopływu promieniowania słonecznego do przeszkleń w okresie zimowym, redukując go znacznie w okresie letnim. Stosowanie przeszkleń $\mathrm{z}$ powłoka selektywną $\mathrm{w}$ energooszczędnym jednorodzinnym budownictwie powinno być poprzedzone gruntowna analizą bilansu energetycznego budynku. Wydaje się uzasadnione w przypadku zastosowania dużych ilości przeszkleń od strony południowej, zachodniej i wschodniej. Przy ilości przeszkleń nie przekraczających wartości $\mathrm{A}_{0 \max }$ korzystne wydaje się zapewnienie zysków słonecznych przez zastosowanie szkła o współczynniku „g” równym przynajmniej 0,5 [3] oraz zastosowanie osłon przeciwsłonecznych, które ograniczą dostęp promieniowania słonecznego do wnętrz w okresie letnim. Należy jednak zaznaczyć, że zastosowanie szkła z powłoką selektywna, o współczynniku g = 0,5, nie zwalnia projektanta budynku z konieczności zastosowania osłon przeciwsłonecznych w okresie letnim od strony południowej, wschodniej i zachodniej. Według obecnych wymogów prawnych [2] współczynnik ten powinien wynosić dla tych orientacji względem stron świata $0,35 \mathrm{w}$ okresie letnim.

Ponieważ budynek energooszczędny funkcjonuje jako system wzajemnie współdziałających ze sobą rozwiązań projektowych, zastosowanych materiałów budowlanych oraz instalacji wewnętrznych, niezmiernie istotne przy projektowaniu przeszkleń w tego typu budownictwie, oprócz doboru współczynników U i ,g”, jest ich rozmieszczenie względem stron świata (liczba przeszkleń powinna zostać ograniczona od strony północnej), brak nadmiernej ekspozycji warstw akumulacyjnych na działanie promieniowania słonecznego w okresie letnim, prawidłowo zaprojektowany system wentylacji, który służy usunięciu potencjalnych, nadmiernych zysków ciepła w lecie (system przewietrzania nocnego), zastosowanie osłon przeciwsłonecznych. Odpowiednie dobranie parametrów okien współdziałających z pozostałymi elementami budynku spowoduje, iż przegrzewanie budynku $\mathrm{w}$ okresie letnim nie nastąpi, natomiast uzysk energii cieplnej z promieniowania słonecznego w okresie zimy przyczyni się do poprawy bilansu energetycznego budynku.

\section{Literatura}

[1] Celadyn W.: Przegrody przeszklone w architekturze energooszczędnej. Kraków 2004, str. 58.

[2] Rozporządzenia Ministra Infrastruktury w sprawie warunków technicznych jakim powinny odpowiadać budynki i ich usytuowanie, 12 kwietnia 2002 r. z późniejszymi zmianami.

[3] Krajowa Agencja Poszanowania Energii: Określenie podstawowych wymogów, niezbędnych do osiągnięcia oczekiwanych standardów energetycznych dla budynków mieszkaniowych oraz sposobu weryfikacji projektów i sprawdzenia wykonanych domów energooszczędnych, NFOŚiGW, Warszawa 2012. 
[4] Chwieduk D.: Wytyczne tworzenia koncepcji energetycznej budynku. Czasopismo Techniczne Politechniki Krakowskiej, 2-B/2012, zeszyt 3, rok 109, str. 45.

[5] www.pilkington.com, dostęp 05-02-2017.

\section{PRINCIPLES FOR SELECTION OF THE TOTAL SOLAR ENERGY TRANSMITTANCE FACTOR OF GLAZING IN ENERGY-EFFICIENT SINGLE-FAMILY HOUSES}

\section{S u m m a r y}

Glazing in energy-efficient single-family housing play a significant role in shaping the energy balance of a building. Heat loss through windows occurs due to transmission. There also occurs heat gain from solar radiation through glazing. Excessive heat gain in the summer can lead to overheating of rooms and is undesirable. The walls of energy-efficient buildings are additionally characterised by a fairly low heat transfer coefficient, making it difficult to discharge excess solar heat from the rooms. The exposure of accumulation layers to solar radiation in the summer is another negative phenomenon. Accumulation layers release the gained heat with a few hours' time lag and their unfavourable position may result in overheating of rooms. Ventilation system which removes excess heat becomes necessary. Excessive solar gains necessitate a more intensive work of the ventilation system, which is conducive to increasing the energy consumption of the building. For this reason, proper placement of glazing in the body of a building, their size, orientation towards cardinal points and parameters of the used glass are extremely important in shaping the structure of an energy-efficient building. The total solar energy transmittance factor (g-value) determines the extent to which solar radiation enters the interior through the glass. A higher value of the coefficient means that energy gains are higher. Solar heat gains in the winter are beneficial and contribute to improving the energy balance of a building. Therefore, shaping the structure of an energy-efficient single-family house should allow for the solar gains in the winter and during the transitional periods, but prevent their occurrence in the summer.

Keywords: energy-efficient single-family houses, total solar energy transmittance factor, solar gains

Przestano do redakcji: 09.02.2017 r.

Przyjęto do druku: 31.03.2017 r. 